\title{
A Historical Analysis of Career Choice among Chinese College Students
}

\author{
Fengyu Wang \\ Shenyang Normal University \\ China \\ Cody Ding (Corresponding author) \\ Educational Psychology, Research, \& Evaluation, University of Missouri-St. Louis \\ MO 63121, USA
}

Tel: 1-314-516-6562Ｅ-mail: dinghc@umsl.edu

Received: March 11, 2014 Accepted: March 27, 2014 Published: April 20, 2014

doi:10.5296/ijch.v1i1.5272 URL: http://dx.doi.org/10.5296/ijch.v1i1.5272

\begin{abstract}
This study provides a historical analysis and review of the contemporary development of career choice orientations among Chinese college students in light of recent economic reform policies. Specifically, it describes the changes in, and developing trends of, career choice orientations in the past, present, and future among college students. This analysis reveals that with the profound transition from a centralized planned economy to a market economy in recent China, students' career orientation has experienced a transformation from a societal standard to an individualistic standard; personal goals have changed from idealism to realism; and ideologies have developed from a unilateral structure to the coexistence of multiple systems. Such an intrinsic link between Chinese college students' career choice orientation and social and economic development has implications for higher education with respect to new requirements for academic programs and curricular content.
\end{abstract}

Keywords: Career choice orientation, Economic development, College students

\section{Introduction}

With the implementation of new economic policy across China in the past two decades, the economy has become the primary factor influencing changes in people's behaviors and value 
systems, especially in younger people. This trend is particularly evident in the evolution of career choice orientations among contemporary Chinese college students. With the increasing role that the market economy has played since 1980, China has created a new situation for career value development as well as for career choices for a new generation of college graduates across the country. This study describes the historical development of changes in young people's career choice orientations and examines the emerging patterns of career choices in the context of the new economic development in China. In this paper, career choice orientation is defined as personal preference in choosing a career or employment according to certain social value system. We focus on the pattern of changes in career choice orientation among college students, that is, students who graduate from high school and go on to the colleges or universities because they have more career choices than high school graduates. In addition, the potential implications of these changes for post-secondary education are discussed. The goal of this analysis is to increase understanding of the social value changes among young Chinese people by highlighting the historical trends in career choice orientations and their potential influences on education. It should be noted that our analysis is primarily based on our personal experiences and observations since there are few available literature on this topic at that time.

The theoretical framework taken in such an analysis was based on the sociocultural materialism perspective stating that human beings are motivated to satisfy biological and psychological needs. It is through socialization and interaction that we learn culturally approved ways of satisfying our biological and psychological needs, and sociocultural progress pushes and channels people into certain behaviors (Elwell, 1999). Although social life is complex, and any theory that attempts to explain all of similarity and diversity of social life would be of little use in our efforts to understand social reality, we adopted such a theoretical perspective because it serves as a guide in organizing our perceptions and insights about facts of evolution of career choice orientation in relation to social changes. In an analysis of evolution of career choice orientation, we recognize that human need for a good career is so important that he/she makes it the centerpiece of his/her life. Such a need may vary through time in one culture--in effect, it varies with cultural values. It is this need for socially approved career that is behind an individual's compliance with sociocultural needs and demands. It also provides the cohesive force that keeps the individual committed to culture with which he/she shares its values.

According to sociocultural materialism, individual's social existence determines his/her consciousness. The concept of career is the focus of the individual as a motivated actor in the sociocultural system. The individual's career is the lifetime pursuit of satisfactions, and its central feature is a person's contribution to the production necessary for the society's continued existence as well as for self in the context of the existing social order (Goldschmidt, 1990). Because the concept of value involves peoples' interests and preferences, the value system has been heatedly debated since humanity has engaged in thought and conscious activity. Such a debate can become more intense when the society undergoes dramatic political and economic changes. According to the social transitions stage model (Pope, 2000), people tend to change their old values to satisfy certain needs under new social conditions. 
From this perspective, value is almost identical to the importance or significance of materials that are imposed by the new economic conditions. For instance, the perspective and value system of an individual as it relates to the importance, significance, and function of objects (e.g., career) determines their value (Lent, Brown, \& Hackett, 1994). The value system becomes an important part of one's outlook on the world and directs people's intentional activities.

This shift in values in relation to societal changes is especially true with respect to the change in career choice orientations in the context of economic reform in China, since selecting a career directly reflects the individual's personal values. The budding marketing economy exposes today's young people to images from around the world through media and the entertainment industry as never before. People's values, especially those of the younger generation, have shifted to accommodate to the "new world" around them. Since China has been undergoing the transition from a centralized planned economy to a market economy, especially a so-called socialist market economy, there has been an unprecedented and profound social transformation (Wang, 1998), which has had an exceedingly lasting impact on people's thought, value orientation, and mannerisms. This impact can clearly be seen from the standards employed by young students in choosing a career--standards that are constantly changing (Li, 2001). Specifically, students' orientation toward career choice is experiencing a profound transformation. For example, their personal core values have shifted from a societal standard (i.e., good for the society) to an individualistic standard (i.e., good for me;Li, 2001); personal goals have changed from idealism to realism; and ideologies have developed from a unilateral structure (i.e., structure set forth by the government) to the coexistence of multiple systems (i.e., benefits for self, family, and the country;Zhao, 1999).

Understanding these shifts would help us to understand the intrinsic link between social and economic development and college students' career choice orientations. In the following sections, we described the various stages of changes in college students' career choice orientation in light of China's employment patterns. This analysis can be useful for policy makers and educators in developing instructional methods concerning college students' future employment. It is hoped that this analysis will be received in a timely manner so as to bring about a resolution to the potential employment mismatch. Note that due to lack of empirical research on college students' career choice during the period before 2000, the assertions made about the phenomenon of college students' career choice were mainly based on information published in the newspapers and the author's personal experiences and observations.

\section{The Changes of College Students' Career Choice Orientations in China}

The course of social development in China has undergone two historical turns since economic reform and opening to the outside world (Cheng, 1999). The first is the time period that we called "class struggle as the focus for social development." This period ended around the 1980s and has been replaced by the second time period, which is generally known as "economic construction as the central task of social development" (Wu \& Yang, 1999). The result is that the traditionally centralized planned economy has gradually been transformed into a market economy (Zhuo, 2002). This shift of core tasks in social policy has accelerated 
social and economic development in China, which has brought about massive shock to college students' orientations towards career choice (Ping, 1995) that exhibit different characteristics at various time periods.

\subsection{First Period (Late 1970s to Early 1980s): Ideological Orientation - Party Interests Are} Above Personal Needs and Everything Else; Career Choice Is Unconditionally Subjugated to the Party's wish

In this period, a person's career orientations took on the characteristic of obeying the needs of society and the state. This was realized by the uniformed education of youth in a value system that placed society and collectivity as the standard under the traditional planned economy (Min, 1997). The organization or the Party determined lifelong ideals, career choices, job allocation, individual hobbies, and even marriages.

After the 10-year Great Proletarian Cultural Revolution (1966-1976) that brought terrible suffering to the people, the college entrance examination system resumed in 1977, and a group of young people with ambition and talents entered colleges and universities. Since they personally experienced the severe hardships and tortuous conditions of the Great Proletarian Cultural Revolution in their lives, their personalities were distorted to varying extents (Liang, 1993). However, due to the constraints of the planned economy, the resulting rigid educational form, as well as the educational content and the social environment of the time, these young college students possessed a unitary political thought and a strong sense of loyalty to the state in a time of difficulty. For example, they listened to the Party's propaganda and devoted themselves to the country's needs because national interests prevailed over everything else (Ping, 1995). Although college students of the time had their own ideals (e.g., having a good material life), they embraced the ideals of the collective good, and thus, they embraced the Party's arrangements for their career choice (Wang, 1996). College students rarely considered their own individual gain or loss. As long as the Party was in need, they were willing to go wherever they were most needed, including the most impoverished areas of China (Weiping, 2002).

The Third Plenary Session of the $11^{\text {th }}$ Central Committee of the Communist Party of China (CPC) in 1978 put forward the primary goal of adjusting and reforming the national economy. From that point forward, China began internally reforming its economic system and externally carrying out economic reforms. Because the turbulence of the 10 -year Great Proletarian Cultural Revolution was coming to an end, all of China was full of life and energy and was suffused with optimism about the future. Substantial problems related to national and personal destiny were topics that every young person was eager to discuss (Jie, 1991). During this period, mainstream values among youth still placed the society and the party interest first. Whatever topics youth discussed, their manner of thinking and pursuit of goals did not depart from this framework of collectivism. The new ideology was still foreign in this generation's value system (Gao, 1989).

Under the traditional planned economy at this time, the state-adopted policy for college and university students was unified enrollment, unified matriculation, and unified career assignment (Xu, 1987). It was unified in that instructional assignment was under the planned 
system. College students became people of the state as long as they entered the universities. Because they would have jobs upon graduation, they were guaranteed to own a "rice bowl." They had no need to consider the problems of finding employment after graduation. Where to work and what to do in those positions were determined by the organization. While college students of the time began to develop a sense of wanting to choose a career on their own, most graduates still complied with the state's assignment when searching for jobs (Xu, 1987). In examining career choices among college graduates, Weipin (2002) reported that college students of the early 1980s ranked their preferences for career choice in the following manner (from highest priority to lowest priority): social status, social significance, individual talent and reward. According to a study by the International Commercial College of Shanghai University, lifelong ideals of Chinese college students changed dramatically during the 1980s (Guofu, 1991). Among 691 college students surveyed in 1982 and 714 in 1989, the percentage of college students who agreed that they should "study to bring prosperity and strength to the homeland as well as to benefit the people" declined from $72.1 \%$ in 1982 to $10 \%$ in 1989 . Those who felt they should "study to be a useful member of society, to get married, and to go abroad" rose from $20.6 \%$ of college students in 1982 to $69 \%$ in 1989 . The percentage of students who agreed with the statement "heaven helps those who help themselves" rose from $5.7 \%$ in 1982 to $58.2 \%$ in 1989 . Clearly, students of the early $1980 \mathrm{~s}$ held values that placed importance on the individuals (Guofu, 1991).

Thus, from the end of the 1970s to the early and mid-1980s, college students' career choice orientation focused on values concentrated on society, emphasizing integrated social values and ignoring individual values. Most people at that time held the belief that there was one, and only one, pursuit in life-- realizing communism and liberating the proletariat (He, 1990). Such a belief was the foundation of moral character among universities until the mid-1980s. Slogans such as "just love whatever your job is" and "just do whatever the party wants you to do" were very popular. In other words, career choice orientation completely entangled with the societal needs.

\subsection{Second Period (Mid-1980s to the Early 1990s): Transition - From a "Social Value Model" to an "Economic Value Model"}

The traditionally centralized-planning economy began to transform into a market economy in the mid- and late-1980s, which broke the mode of unified instruction and job assignment of college students after their graduation. "Decisions on the Reform of the Educational System," promulgated by the Central Committee of the CPC in May 1985, listed several points regarding the planned educational system of enrolling college students and the career assignment system (Lin, 1985). The Central Committee agreed that they should change the methods by which colleges and universities enroll new students. They further agreed that the state should no longer be responsible for assigning all graduates to employment upon graduation. Instead, the Central Committee agreed to implement a system in which students fill out applications, schools recommend students, and employers pick the best students to employ under the direction of the state plan in assigning graduates. This document established a foundation for reform in colleges and universities as to how their graduates would become employed. For the most part, graduates at the time used universities as a 
means to find employment.

At the same time, college students began to orient their career choices toward more materialistic and utilitarian endeavors at an ever-quicker pace. The social values before economic reform emphasized the intangible values of society, but did not embrace materialism. Ideology was the most important standard in the assessment of values (Zhu, 1994). With the economy becoming the primary aspect of social life, the value of material possessions began to increase. A survey of students' attitudes in colleges and universities in 1986 (859 senior students) and 1989 (962 senior students) showed that the percentage of students who thought that life's value was established by making contributions to society and obtaining rewards from it rose from $47.7 \%$ in 1986 to $70.1 \%$ in 1988 . However, the percentage of students who were willing to contribute unconditionally to society decreased from $47.1 \%$ in 1986 to $25.1 \%$ in 1988 (Cunku, 2000).

College students of this period usually chose employment in government offices, colleges and universities, and other institutions owned by the state (Rong, 1996). However, because their concept of career choice had transferred from a social value model to an economic value model by the end of the 1980 s, students started to place personal economic interests and material rewards in important positions in their value systems (Rong, 1996). According to a 1988 study by the Youth Research Office of the Chinese Academy of Social Sciences, out of 1452 college students surveyed, $31 \%$ percent of students wanted to work in "three types of enterprises: Sino-joint venture, cooperative business, and exclusively foreign-owned enterprises in China" after graduation, whereas only 13\% were interested in Party and government offices (Xiong, 1997).

Therefore, from the mid-1980s to the early 1990s, the emerging market economy in China dethroned idealism from its place in societal values. With the Western influences of existentialism, materialism, and pragmatism, most college students began to consider idealism as too disconnected from real life (Wang, 1994). Thus, their career choice turned to practical benefits that would improve their material needs. A study of the career values of college students in the $90 \mathrm{~s}$ found that the main criteria for career selection were income, social class, power, and job stability (Zhijian, 1997). Slogans such as "ideal, ideal, money is my ideal" and "all for the money" have become popular among most college students. Thus, after a long period in China, career choice of service to society have finally been replaced by choices that stress the individual, monetary, and material pursuits.

\subsection{Third Period (1990s to the Present): Materialistic Orientation - Multiple Entities, Practicability, and a Strong Influence of Materialization in Career Choice}

With the gradual permeation throughout China of the market economy in the early 1990s, the system of state-assigned job to graduates gave way to the free career choice (Rong, 1996). Market demand acted as the guiding force in this new economic condition. The multiple aspects of market demands inevitably made college graduates conform to these demands. This vastly extended the list of career choice options available to college students while strengthening graduates' willingness to take risks and engage in free career choices (Song, 1995). They actively marketed themselves to seek a career suitable to their own needs. 
Students' attitudes towards their career changed from the simple pursuit of a career with social status to the pursuit of profitable careers (Die, 1992). They looked for careers that allowed them to realize their value as individuals and their usefulness as human beings (Cunku, 2000). Therefore, selecting a career that could support them as well as allow them to realize their self-worth through hard work and career progression became a realistic orientation of college students when making their career choice. At this time, many college students took on the view that working in a market economy meant complying with the principal of free movement and survival of the fittest, and that every job change meant taking a higher step in their career (Be, 1998).

A longitudinal study by Beijing University reflected the changing focus of college students' career value orientation in the early 1990s (Cunku, 2000). The following were college students' career choice orientations ranked in order of most important to least important:

1991: scientific research; cultural and health departments; enterprises in the forms of Sino-joint venture; cooperative business and exclusively foreign-owned businesses in China; party and government offices

1992: colleges and universities and scientific research units; enterprises in the forms of Sino-joint ventures; cooperative business and exclusively foreign-owned enterprises in China; party and government offices

1993: enterprises in the forms of Sino-joint venture; cooperative business and exclusively foreign-owned enterprises in China; going abroad to work; colleges and universities and scientific research units

1994: special zones in coastal areas; enterprises in the forms of Sino-joint venture; cooperative business and exclusively foreign-owned enterprises in China; working in a foreign country

Clearly, there has been a shift in career choice to more materialistic values model during this time.

Thus, development of a market economy in the 1990s accelerated college students' general sense of individuality, and college students' value orientation toward materialism became more manifest. In 1994, the People's University of China in Beijing found that among 513 senior college students, $72.5 \%$ of them wanted to learn practical knowledge; $73.2 \%$ thought that literary, historical, and philosophical knowledge were useless; and 69.6\% considered doing research to be boring, impractical, and not financially rewarding (Cunku, 2000). In addition, college students considered these factors when selecting jobs: income (cited by $78.4 \%$ of students), opportunity for self-fulfillment (59.6\%), power and social status $(55.6 \%)$, comfortable work and/or located in cities (53.7\%), and opportunities to go abroad for further study $(32 \%)$. These numbers are enough to show that college students' designs for their own development placed individual needs and practicability at the heart of their decisions about their careers. Similarly, in a March 1996 survey of 250 students from Beijing University, 206 students rated the following factors as important influences on their career choices: income (73.3\%), utilizing their talents $(50 \%)$, time for hobbies $(36.4 \%)$, quality of the working 
environment (34.5\%), utilization of special skills $(28.2 \%)$, social status $(18.0 \%)$, and promotion opportunities (14.6\%) (Cunku, 2000). Not surprisingly, in light of the importance of financial reward in college students' career decisions, graduates are favoring foreign-capital enterprises and financial organizations. Of the 198 students who answered the question regarding the importance of a satisfactory workplace, $41.5 \%$ of them chose foreign-capital enterprises and $29.3 \%$ chose financial organizations. The percentage choosing scientific research careers was $19.2 \%$; $4.1 \%$ chose industrial enterprises and $5.6 \%$ chose media jobs. Because of the offer of steady income, government jobs have also held some appeal for graduates.

The social transformations and reforms not only bring economic improvements and prosperity in the standard of living, they also bring about changes in people's ideologies, ways of thinking, life styles, and values. College students are among those most susceptible to these changes. In order to meet the increasing demand of material needs, their career choice orientations are forced to change, showing a close tie to economic development. The concepts of self-consciousness, entrepreneurship, achievement, desire, and responsibility have taken hold in China. Slogans such as "work for money and self-fulfillment" characterize the trend in career value and choices during this period (Be, 1998).

\section{Changing Trends in the Career Value Orientation of Future College Students}

To a considerable degree, the changing trend in career choice orientation for college students lies in the development of both China's society and economy. The political era of class struggle has gone forever. The advent of the $21^{\text {st }}$ century has brought a new economic era. The future of college students' career choice orientation may, to some extent, show the following characteristics.

\subsection{Coordination}

In certain aspects, individual values and social requirements are conflicting, if not completely opposite. Societal needs require individuals to conform to social obligations, while college students are aware of the fact that the current society provides them with a wide array of opportunities for prosperity. It is true that most young people actively select enjoyable professional and personal lives based on their own interests in the market economy. But there is a need to coordinate the two value systems, avoiding conflict. Thus, college students need to consider both material gain and contribution to society.

\subsection{Multilevel}

Experiencing the political frenzy of the 1970s, enduring student strikes of the 1980s, and embracing economic upheaval of the 1990s, current college students' political positions step toward impersonality and even detachment. They will use individualized means of becoming involved in social activities, and their focus will be on pursuing social justice and social order in light of their personal values. College students will judge their career by personal standards, favoring self-fulfillment and self-development. They will place importance on satisfying their needs for respect, achievement, and expression of the self as well as improving their standard of living and their life style. 


\subsection{Individualism}

In the new economic era, the system by which Chinese graduates attain employment has shifted from unified distribution to mutual selection by the employer and employee, and to the selection of employer by individuals (Sheng, 2001). People have basically come to accept the concept of self-seeking employment. Thus, market-driven employment has become a generally accepted career choice orientation ( $\mathrm{Li}, 2002)$. It would appear that college students will explore those careers that enhance self-values and achievement. Young college students enjoy new fashions, new ideas, and new ways of life. Attaining a higher level of education, a higher professional class, a higher salary, and a higher standard of living have become their targets.

\subsection{Practicality}

Although economic development provides an opportunity for self-development, college students may need to adapt to cruel market competition and the principle of survival of the fittest. The advancement of technology, the expansion of knowledge, and the technical complexity of products will exacerbate competition among enterprises. The needs for specialized knowledge turn to the needs for talents in the new economic system. In choosing workers, an employer's level of demands for candidates' talents and knowledge become higher and higher (Liu, 2003). Thus, pursuit of advanced education, graduate school, and certificates has become necessary. Those who fail to do so will fall behind and become unmarketable. In addition, the cold fact of survival of the fittest will force college students to be more realistic in their career choice, even if it means giving up their newly adopted career values.

\section{Implications for Post-Secondary Education}

Because of rapid economic development and ever-changing science and technology, higher education must keep abreast with the latest developments. Due to the dramatic shift from education for the elite to education for ordinary people, many challenges quickly emerged before there was time to consider what had been done. With the increased enrollment of students in colleges and universities in China, the issue of quantity is resolved. However, the issue of quality has become the hot topic for post-secondary education. Pursuit of individualized career choice means the mastery of specialized knowledge. Can the universities and colleges prepare their students for such a need? What are the implications for post-secondary education? What have the universities done to meet these challenges?

\subsection{New Requirements for Academic Programs and Curricular Content}

As knowledge becomes a key economic component, the knowledge structure and quality of educational programs need to be updated. This may require the structural adjustment of higher education in terms of teaching content and programs offered in response to market demands and changes as well as their own needs in order to enhance their adaptability in the context of economic development. For example, Liaoning province in northeast China is an old industrial base with outdated technology and manufacturing equipment. In order to revitalize local industry, it has started to develop industries that focus on information 
technology and new high tech sectors. As such, it attaches great importance to the development of such leading academic programs as IT and microelectronics, software development, bioengineering, mechanical-electrical integration, new energy sources, modern agriculture, and modern communications. Thus, instructional content and methods are reflective of the development of science and technology.

\subsection{Improving Teaching Methods in Higher Education}

There is a direct relationship among the quality of higher education, teaching content at colleges and universities, and the levels of development in technology and the economy. On the one hand, whether teaching materials are current depends on teachers, but on the other hand, it also depends on whether methods of teaching are current. More advanced teaching methods help students learn better. For example, application of multimedia technology in the classroom enables learning materials to be more visual, intuitive, and dramatic, making it is easier for students to take in the content. Furthermore, learning and teaching materials themselves require advanced teaching methods. For example, courses in computer applications are unable to be offered without the use of computers. Thus, the choice of teaching methods itself is also a process for students to master new technologies.

Such applications of new educational technology not only have allowed teachers to be more effective in terms of efficiently utilizing resources, but also have allowed for frequent updating of teaching materials. Thus, the educational coverage and depth have been greatly expanded, which enables education to become an increasingly individualized learning process. At the same time, it increases the quality of the education. The consequence of such influences of economy on education is the supply of new human resources and talents needed for further economic growth.

\section{Conclusion}

The purpose of this paper was to describe the evolution of college students' career choice orientations and the background in which these changes have occurred. The changes in the old career choice orientations were unavoidable during the transformation of China's society. The empty and idealistic rhetoric of previous times were unsuccessful in enriching the lives of China's 1.3 billion citizens. The change in career choice orientations re-affirms the positive significance of materialism that has been embraced by college students. However, society should not embrace materialism as its only principle. People have ideals and spiritual needs as well as material ones. Although the importance of money in the lives of people cannot be overlooked, avoiding enslavement to money is also necessary.

\section{References}

Be, H. (1998, August 21). New ideas in job choice and the consequences. LiaoNing Daily, p. 2.

Cheng, X. (1999). Current trends and thougts. Beijing: Chinese Academy of Social Sciences.

Cunku, Z. (2000). Professional values for 1990s college students. Exploration of Youth, 1, 23-24. 


\section{Macrothink}

Die, X. (1992, January). The job rush in the sourthen cities of China. YangChen Evening News, p. 1.

Elwell, F. W. (1999). Industrializing America: Understanding comtemporary society through classical sociological analysis. Westport, Connecticut: Praeger Publishers.

Gao, J. (1989, April 24). Keeping with the current social trend is needed in today's society. Tianjing Daily, p. 4.

Goldschmidt, W. (1990). The human career: The self in the symbolic world. Cambridge: Basil Blackwell.

Guofu, T. (1991). Deviation and restructuring of youth spiritual support. Youth Studies, 4, 5-6.

He, W. (1990). What do we believe and why do we believe. Shenyang Normal University Academic Journal, 1, 4.

Jie, H. (1991, March 8). The new phenomenon of discussion among today's youth. Youth Daily, p. 3.

Lent, R. W., Brown, S. D., \& Hackett, G. (1994). Toward a unifying social cognitive theory of career and academic interest, choice, and performance. Journal of Vocational Behavior, 45, 79-122.

Li, J. (2001, July 21). What are young people looking for in work? Liaoning Youth Daily, p. 2.

Li, J. (2002, October). The development of market economy in China. HaiNan Daily, p. 2.

Liang, R. (1993). How should we evaluate cultural revolution? ShengZeng Daily News, p. 5.

Lin, L. (1985, May 16). Decisions on the Reform of the Educational System. People's Daily, p. A2.

Liu, Y. (2003). The needs of employers and education of college students. HeNan University Journal, $1,6$.

Min, T. (1997, May 15). The effects of social values on career choice in young people. JieFang Daily, p. 3.

Ping, Y. (1995). The youth career pursuit in urban city. Beijing Daily, p. 5.

Pope, M. (2000). A brief history of career counseling in the United States. The Career Development Quarterly, 48, 194-211.

Rong, Y. (1996, September). Change in college job choice in recent years. People's Daiy, p. 5.

Sheng, J. (2001, September). The realization of individualism through job choice: The new idea. Shanghai Daily, p. 4.

Song, J. (1995, June 22). The boom of economy and choice of jobs in current China. HaiKou 
Evening News Daily, p. 2. 2014, Vol. 1, No. 1

Wang, C. (1996, November). The position of party in youth career selection. People's Daily, p. 2.

Wang, F. (1994, June 9). The influence of western ideas: The current trends among college students. Youth Daiy.

Wang, H. (1998, May 14). Current social change in China. People's Daiy, p. 4.

Weiping, W. (2002, Janunary 16). Report from the investigation into the employment market of Chinese college students. China Youth Daily, p. B1.

Wu, D., \& Yang, H. (1999). Socialist democratic politics with Chinese characteristics. Beijing: Social Science Documentation Publishing House.

Xiong, Y. (1997). Changing features and developing trends for Chinese college students in the 1990s. Youth Studies, 9, 7-8.

$\mathrm{Xu}, \mathrm{L}$. (1987). The outlets of job for today's college students. Journal of Beijing Normal University, 3, 15.

Zhao, X. (1999, August 10). What do people believe in urban city of China. Beijing Evening News, p. 6.

Zhijian, H. (1997). Comment on youth at turn of century. Beijing, China: Youth Publishing House.

Zhu, X. (1994). Current ideology in China. HuaDong Normal University Academic Journal, 3,5 .

Zhuo, H. (2002, June 18). Transformation of Chinese economic system in recent years. GuangMing Daily, p. 2.

\section{Copyright Disclaimer}

Copyright reserved by the author(s).

This article is an open-access article distributed under the terms and conditions of the Creative Commons Attribution license (http://creativecommons.org/licenses/by/3.0/). 